\title{
COLOMBIAN MILITARY TRANSFORMATION: STRATEGIC REALITY AND OVERCOMING RESISTANCES
}

\author{
Víctor M. Mijares ${ }^{1}$ \\ Paula Alejandra González²
}

\section{Introduction}

In 2012, after more than 50 years of conflict, Colombia's President Juan Manuel Santos initiated the process of peace talks with the oldest and biggest Latin America's communist guerilla, the Revolutionary Armed Forces of Colombia (FARC). The agreement was signed in 20I6. More than 7,000 FARC members would be reinstated in the Colombian society after handing over their weapons under UN supervision. Meanwhile, the political and economic situation in Venezuela kept deteriorating, leading to an increase of criminality in the border and the arrival of roughly I.5 million migrants and refugees to Colombia till 2019.

While this scenario is in the making, an important strategic issue in Colombia is the need to transform its military forces. During the conflict, the Colombian military focused on counterinsurgency (COIN). To some extent, this implied that other typical defense functions, as land border, maritime, and airspace patrol and protection, did not receive the same attention within the national security strategy. However, with the recent FARC disarmament process it became imperative to change the military by transforming its doctrine, reforming its functions, and eventually right-sizing its manpower.

This proposal of change was led mainly by former President Santos and the Colombian High Command. Nevertheless, this raised some fears and resistance, especially in the middle-ranks of the military, since the possibility

I Assistant Professor from the Departament of Political Science at Universidad de los Andes, Colombia.

2 Master Student from the Department of Political Science at Ruprecht-Karls-Universität Heidelberg, Germany. 
of reducing the size of the army was on the table. However, the transformation started focused on the doctrine. Thus, it is relevant to ask why and how the Colombian military is going through a process of transformation despite of the resistance of some of its sectors. To answer this question, this paper is divided as follows: first, we will define and address the transformation of the military forces as well as the Colombian new military doctrine. Then we expose the explanatory model to be applied to understand the case, as well as the methods for driver selection and analysis. Third, we will select the variables that compose the drivers (as causal mechanisms) of the military transformation and then test those with process-tracing.

\section{Changes in the Colombian military: New Doctrine and Resistances}

As Prezelj et al. (2015, 25-26) argue, a military transformation is a national policy with the purpose of changing and improving military capabilities. This can happen due to different kinds of inputs, internal and/ or external. Thus, security threats, international organizations, regional cooperation initiatives, as well as genuine national needs are among the inputs that can lead to a military transformation. That brings outputs such as changes in the military culture and mindset, in the military tasks, and in the military training and education, or in the acquisition of new technology and advanced weapons.

On the other hand, as the concept of "security sector reform" points out, for countries that transits the path of post-conflict, security agents have a main role due to the usual instability that characterizes this period. Therefore, in such contexts it is common to generate reforms that contribute to assure that the police and the military forces are well-equipped and prepared to face the challenges that come with the ending conflict, and that they operate in line with the principles of a democratic governance, the rule of law, and the respect for human rights (Jingushi 2015, 40-44).

On August 6th, 20I6, General Commander of the Army Alberto José Mejia presented the results of the first stage of the plan to propose a structural transformation of the Colombian Army. According to him, this change would be the most important one in the last century of Colombian military history, in order to have a renewed, more effective and "closer to thepeople" army (El Tiempo, 20I6). At the base of this transformation is the so-called "Damasco doctrine”. This innovative doctrine dates back to 20II. Two years before, in 2009, FARC had changed its military strategy, shifting from the concentration 
of big combatants' groups to the pattern of small cells committing attacks across the national territory. Therefore, in $201 \mathrm{II}$ it was necessary for the army to start planning how to innovate its strategies and tactics to have a more effective fight against them (Rojas 20I7, II2). That was the beginning of a process of institutional reengineering.

One year after, in 2012 the Santos government publicly announced the decision of initiating a peace process with the FARC. This implied the possibility that some years later the biggest threat to national security so far could be disarmed. Accordingly, the army would also have to adapt to the new circumstances of the national scenario and the possible new challenges that it would have to face. Thus, in 2013 the Strategic Committee for Designing the Army of the Future-(CEDEF) took over the goal of creating a plan to review the army's doctrine (Gómez and Correa Henao 20I4; COTEF 20I6).

In 2015 the Education and Doctrine Command (CEDOC) implemented the "Minerva Plan," aimed to design a doctrine and an educational system that could articulate basic components such as doctrine, education, instruction and training, science and technology, and lessons learned, in order to have a better trained and even more professional army (CEDOC 20I6). One of the most important projects included in this plan, was the Damasco Project. The Damasco doctrine was structured by the team of the Army's Doctrine Center (CEDOE), which included military and civil professionals, with the support of the US Southern Command and a Chilean army mission. The new army's doctrine framework would follow four different phases, such as: the first stage would be the publication and distribution of the I7 Fundamental Army Manuals (MFE), which were presented in August 20I6. The second part are the Fundamental Reference Manuals of the Army (MFRE), the third phase are Army Field Manuals (MCE), and the last stage are the Army Technical Manuals (MTE) (Rojas 20I7, 269-27I). All these documents contain the philosophy, tactics and strategies that will guide the Colombian army and are expected to be published and available by 2020 (El Tiempo 20I6).

To understand why this is a transformational doctrine, and one of the most important changes in the Colombian army history, it is important to briefly review the profile of the doctrine's development. In I907 after having experienced the "Thousand Days War", the Colombian military was reformed with the assistance of a Chilean military mission. By this time some of the most important high military education institutions were founded such

3 The Guerra de los Mil Días (I899-I902) was a civil war between the Liberal and National parties coalition, and the Conservative party. The outcome was a Conservative victory, the weakening of the Liberals, the dismantling of the National Party, and almost a 1००,০०० deadtoll. A year later Colombia lost Panama. 
as the Escuela Superior de Guerra and the Escuela Militar de Cadetes. During this period, the Colombian military was strongly influenced by the Prussianstyle thought. Later during the Cold War, the army participated in the Korean War and since then begun the process of "Americanization" of the doctrine. Until then, the Colombian army was trained and focused on conventional and regular warfare. A decade later and after the guerrillas rise, the military suffered a drastic change, focusing its training and efforts on irregular warfare, particularly on COIN (Rojas 20I6, III-II3).

Hence since the ig6os the Colombian army doctrine had been characterized by a Cold War mindset. While they had developed superb COIN capabilities, conventional and regular warfare were somehow neglected. In practical terms, and according to the Colonel Pedro Javier Rojas: “[...] the operational concept of the Army did not evolve to the operational postulates of the Air-Ground Battle (i986), Operations of Total Dimension (1993), Operations of the Total Spectrum (2008) and Unified Terrestrial Operations (20I2), which are currently used by aligned armies with the NATO doctrine"4 (20I6, II4).

The Damasco doctrine was envisioned to think about the army of the future. The main goal is to become a "multi-mission" army by 2030 . However, to achieve this, ideological and operational changes must be implemented, which are contained in Damasco (Rojas 2016, 98), as follows. It recognizes that in Colombia, instead of a terrorist group, there is an internal armed conflict and that there are other internal and external threats and challenges that the army must be ready to combat and face. It will not be completely focused on the insurgency. Thus, the army is overcoming the cold war thinking and trying to ensure the respect for the international humanitarian law. Also, the Colombian army must be aligned with the NATO international standards. This means twofold, the army must expand its functions and improve its capabilities for conventional and regular war; and the institution needs to be better educated in military sciences, in order to be ready to participate in joint missions with NATO allies and partners, and respond to regional and hemispheric challenges.

Additionally, the army mustbeguided by theinternational humanitarian law. The institution has always been respectful of democracy and the civil rule, but some of its members have also committed crimes against international law. Thus, the new doctrine emphasizes the relevance of recognizing who is the enemy and its nature, in order to comply with international norms. Thus, the army's duty should not only be focused on providing conventional national

4 Authors' translation. 
security, but also on human security. According to the former commander-inchief of the armed forces, General Alberto José Mejia, the army must be ready to serve the communities and work with them to supply their needs.

The first I7 booklets that contain this new philosophy are available online. This is the first time that the army has published its doctrine and that the citizens have free access to it. Thus, this doctrine seems to recognize that the national reality is changing and the internal and external threats to the national security as well. Accordingly, the army must adapt to the new conditions, be ready to fight diverse threats, provide security for the postconflict phase, keep being an important agent in building state capacities in Colombia ${ }^{5}$ and comply with the international standards of NATO.

Despite the attractiveness of innovation, multi-mission army, and the army of the future, this process of transformation also generated resistance in some sectors of the Colombian military. This resistance, of course, was reinforced by all the fears and doubts that the military has been showing about the peace agreement with the FARC.

It is methodologically difficult to show evidence of this point, given that the military must comply with their constitutional mandate of not participating in politics and accordingly they avoid publicly criticizing or expressing their views on political issues and the civilian rule. However, there are two journalistic investigations that present facts and ideas collected from conversations with insiders. One is the work published by the Colombian online political journal La Silla Vacía, written by Juanita León. Another one was published in colombiapeace.org by the Washington Office on Latin America (WOLA). Both refer to the peace process and not explicitly to the transformation of the military. Nevertheless, it is important to note that much of the criticism and opposition led by former President Alvaro Uribe to the peace process had to do with the role of the military, saying that the negotiations with the FARC were a disrespect for the military forces and that the Santos administration would reduce the size of the Army. Thus, the disagreement with the peace process can also be related with the resistance to the transformation of the military forces.

According to WOLA (2015), there are at least three events that show the military uneasiness. First, in 20I3, international guarantors and Red Cross' personnel had the delicate mission of transporting FARC negotiators from the Colombian jungle to Havana. However, someone with a high rank in the military shared the secret coordinates of the pickup zone with former

5 Building state capacities in post-conflict is a paramount task in order to avoid new forms of social conflicts. Alex Jeffrey explained this for local case is Bosnia-Herzegovina (2006). 
President Uribe and he posted it on Twitter (Semana 2013). Second, in 2014 the newsweekly Semana published a report revealing the existence of a secret office of the national army with a restaurant facade, where the government negotiators in Havana were being hacked. According to it, this office started functioning one month before the public announcement of the initiation of the peace dialogues made by President Santos and worked for a year without the consent of the government (Semana, 20I4). This raised concerns that the Military Intelligence Center (CIME) could be a central point of opposition to the peace agreement within the army. And third, in Colombia the Association of Retired Officers (ACORE) is seen as a de facto speaker for the political opinions of active-duty officers, given that it is constitutionally prohibited for them to express them. ACORE has been vehemently and regularly critical about the peace agreements and former president Santos.

On the other hand, León (20I4) presents four fears that sustain the uneasiness of the military regarding the peace agreement. First, the fear of losing labor stability: in comparison to other professions in Colombia, the military have many social privileges, such as job security and the possibility of retiring young, because they put their lives in risk to protect the country. However, if war ceases due to the peace agreements the risk for their lives would not be the same and therefore, they could lose their social privileges. In the words of retired general Rafael Colón, what some military say is "They are going to restrict our rights in terms of health, social benefits. They are going to remove my layoffs after having fought for this country".

Second, fear of trials. The army is one of the most respected institutions in Colombia. However, with the end of the conflict there is also a truth commission, where it is expected to give voice to the victims, so they can tell the truth about what happened. It is well known that some members of the military committed crimes against the civilian population and that it should be disclosed in the truth commission. However, the army does not want to lose its social prestige or be remembered in history as rogue.

There is a controversial fear of losing defense contracts. The defense sector in Colombia is huge and it involves many contracts and daily transactions where retired officials play an important role. For more than 50 years, this was justified due to the internal armed conflict and the need to have huge military forces. However, the end of the conflict might imply that this need disappears and accordingly the size of the military forces could be reduced. Regarding this point, the active-duty officers are scared of losing their jobs and the retired officers would not like to lose profits from a vast defense sector.

And fourth, the ideological issue. The military were educated for 
more than 50 years with a cold war counterinsurgency doctrine. For them, the FARC were the biggest enemy, the one that had to be fought as hard as possible. Especially under the Uribe government, the instruction was to have a military victory over the enemy. Besides, the military have not only seen but also self-experienced the consequences of the violence inflicted by the FARC. Therefore, it is difficult for many of them, to accept that the enemy of a lifetime, the FARC, have now a political status and must be treated according to this.

Thus, it is possible to see that one of the biggest reasons of unease for the military is the ideological issue. Stopping to treat the FARC as the enemy and having the duty to protect their lives is something that touches the feeling of honor and pride in some sectors of the military. Although they have not expressed concerns regarding the project of transformation of the army, one should not forget that this change of the National threat and the status of the enemies is an idea included in the new Damasco doctrine.

The idea of transforming the Colombian army and its process of change emerged in a very different country in comparison to the Colombia of the last two decades. Being one of the oldest and most stable democracies in Latin America, during the I990s and the early years of the 2Ist century Colombia was about to be considered a failed state, almost at the same level as Rwanda and Afghanistan (Merchán 2005). This was due to the permanent territorial dispute among illegal groups such as the Ejército de Liberación Nacional (ELN), Autodefensas Unidas de Colombia (AUC) and the FARC. Besides, the country was not even close to be recovered from the consequences of the violence inflicted by the Cali and Medellin cartels, and the political institutions were weak and full of corruption (Shifter and Jawahar 2004, I44- I45).

In such a context, the Plan Colombia was implemented and with the cooperation of the United States the Colombian military went through a process of modernization and professionalization. With a much better equipped and more modern military forces, the government of the president Alvaro Uribe (2002-20IO) led one of the most effective and successful battles against the FARC (Toro 20I0), resulting in the killing of its second commander Raul Reyes (Rico 2008), the weakening of this guerrilla and its withdrawal of some territories. The government of Juan Manuel Santos started in 20I0, and under his presidency the army kept demonstrating its effectiveness with the killing of the FARC commanders "Mono Jojoy" in 20I0 (Lozano 20IO) and "Alfonso Cano" in 20II (El Espectador 20II). By this time, Colombia had already started to change, improving its economic and security indicators. The military forces had a total personnel of around 450.000 people and this amount would increase to $48 \mathrm{r} .000$ in 2016 (World Bank 20I6) and the 
military expenditure as percentage of the GDP was 3.39\% being the highest in South America (SIPRI 20I8). With a population of around 50 million inhabitants, the country had in 2016 a GDP of US\$280.09I billion (Bank 20I8), the population living below the poverty line went from $55 \%$ in 2002 to $26.9 \%$ in 2017 and the unemployment decreased from $17.4 \%$ in 2002 to $9.2 \%$ in 2017 (DANE 20I7).

Thus, despite of the resistance to the transformation, Colombia has changed, and the process of military transformation started in 2015 with the writing of the first I7 booklets of the Damasco doctrine and nowadays it is still an on-going process. This is due to the influence of the national and regional contexts. More specifically, the internal armed conflict of Colombia changed with the peace agreement signed between the government and the FARC. But also, the Venezuela's domestic growing crisis had directly affected Colombia in different ways, even highlighting the possibility of a military confrontation with this neighbor.

\section{Overcoming Resistance: Process Tracing of the Path Towards Military Transformation}

The military transformation of Colombia is an ongoing process. However, changes in doctrine and practices are already self-evident. Beyond the official reasons, the underlying causal mechanisms remain opaque lacking studies to identify them and offer a comprehensive explanation. In order to achieve this analytical product, we worked within a causal research design, having the in-depth case study as methodology and making use of process tracing. The data and information that we have collected, comes from primary and secondary sources, such as military manuals, interviews published online, and diverse scientific articles, among others.

Based on this, we hope to develop an empirically verifiable association between the causal mechanisms (the drivers) and the transformation of the Colombian military forces. That is why the chronological line in which the drivers could have caused the observable outcome are important. We try to rule out spurious variables by taking care on their selection. Thus, after gathering deep knowledge of the case study, we found out that there are three variables that coincide chronologically with the beginning of the transformation process and which due to its nature have an impact on it, namely: the changing nature of the domestic conflict, the renewed confrontation with Venezuela, and the NATO partnership. Therefore, we select them as drivers for the outcome in the model that we propose. The causal design allows us to understand the 
mechanics behind the operation of the phenomenon studied through the process of showing a causal link between variables.

Another virtue of this research design is that, even starting from a case study, it is possible to replicate it in similar cases or in demonstrations that put the same case study to the test. Given that we start from a systematic selection of causal conditions and an equal test for all, the study can have internal validity. While causality in social phenomena can only be inferred, but never proven, we take note of observable manifestations that account for the selected variables. From these we apply a form of process tracing based on an explaining-outcome (Beach \& Pedersen 20I6, 3), reconstructing the causal chain that preceded the Colombian process of military transformation.

The process tracing methods allow exploring causation between a condition and an empirically observable outcome. Its virtue is to go further beyond the correlation, inferring causality through the concatenation of intervening variables, not necessarily causal to each other. The explainingoutcome process tracing is "a single-case study that seeks to find the causes of a particular outcome. The ambition is to craft a minimally sufficient explanation, with sufficiency defined as an explanation that accounts for all of the important aspect of an outcome with no redundant parts being present" (Beach \& Pedersen 20I6, I78). The explanation is constructed from a causal mechanism, a "theorized system that produces outcomes through the interaction of a series of parts that transmit causal forces from X to Y. Each part of a mechanism is an individually insufficient but necessary factor in a whole mechanism, which together produces Y. The parts of causal mechanisms are composed of entities engaging in activities" (Beach \& Pedersen 2016, I76).

In the case of the Colombian military transformation, causation arises from the imperative need for the material and strategic modernization of the Colombian Military Forces. However, the step from the Material and Strategic Modernization Imperative (X), to the Military Transformation (Y) is not automatic. Causality must be inferred through a causal mechanism that pretends to be the specific explanation that is still lacking in the literature about an ongoing process. This theoretical system is composed of three intervening variables that, by themselves, fail to explain the step towards modernization, that is, they are insufficient. Nevertheless, in turn, their presences have been necessary for the result. Thus, as was mentioned before the causal mechanism is composed of the signing of peace agreements with the FARC, which entails a change in Colombia's armed conflict and in the main threat to national security. On the other hand, and associated with the above, is the renewed confrontation with neighboring Venezuela, which in the last fifteen years has acquired Russian weapons systems that have been 
perceived as threatening to Colombia. And third, the new status of Colombia as NATO's Global Partner, which is a new challenge for the armed forces that have been fighting a COIN war for more than half a century. In the following figure, we can see the causal inference proposed for the case we are studying:

\section{Figure 1}

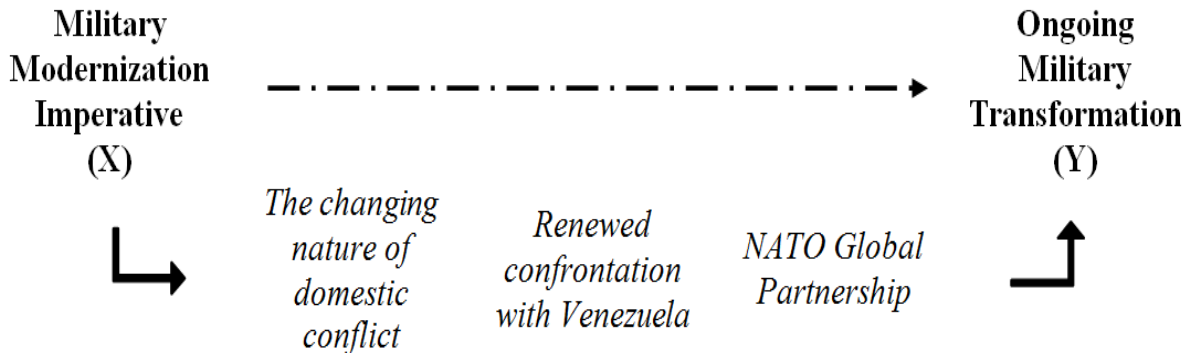

Source: Prepared by the authors.

\section{The Changing Nature Domestic of Conflict}

With the signing of peace agreements with the FARC, the nature of the Colombian armed conflicts had begun to change. On November 24, 2016, the government of Juan Manuel Santos reached an agreement of total cessation of hostilities with the largest and oldest war in the Western Hemisphere. This not only has a relevant political impact for Colombia and Latin America, but also imposes a new challenge for the Military Forces of that country. The COINtype struggle that the Colombian State has been waging in its consolidation managed to specialize its armed forces in a form of combat not coincident with those developed in the rest of South America.

The peace process is still far from being fully materialized, while the implementation of the clauses of the agreement with the FARC remains a difficult process to carry out, due to weaknesses of the State, the present of spoilers and other violent actors, as well as the persistence of FARC dissidents the field. Additionally, the second largest guerrilla in the country, the ELN, remains active after the government broke the peace negotiations in January (Molano 20I9), which maintains the inertia of the COIN struggle within the framework of the doctrine of the Military Forces. Finally, we must not forget that the change of government, with the arrival of the right-wing Democratic Center party member Ivan Duque, has generated fears about the continuity 
of the process. Despite these obstacles, the fighting has been reduced ${ }^{6}$. The main indicator is the occupancy rate of beds in the Bogotá Military Hospital (HMB), which historically was the center of attention for wounded or deceased combatants. By mid-20I7, eight months after the signing of the agreement with the FARC, the number of occupied beds of the HMB fell by 97\% (El Espectador 20I7), while by $20 \mathrm{I} 8$ only one soldier was taken care of (RCN 20I8). This clearly indicates that the Colombian internal conflict is changing, forcing the military transformation.

\section{Renewed Confrontation with Venezuela}

Colombia and Venezuela share a border of 2.219 $\mathrm{Km}$ and a history that in the last 20 years has been turbulent. Both countries were the main players in almost two thirds of the total South American militarized interstate disputes in the last 150 years (COW 2OI7). During the first years of the 2Ist century, Venezuela was the second most important trade partner for Colombia. Besides, the mutual border is one of the most active ones in the region, due to the amount of goods, services and people that regularly cross it every day. Thus, it is difficult to think about the possibility that whatever happens in one of these countries, would not affect the other. While for decades Venezuela received millions of Colombians running from socioeconomic inequality, social violence, and the internal armed conflict, now there are thousands of Venezuelans fleeing daily to Colombia trying to escape the crisis that has led the country to the verge of collapse.

In the last five years, the political and economic crisis in Venezuela has only worsened. According to the IMF data, the GDP has decreased in $45 \%$, half of the economy had disappeared, hyperinflation might reach $1.000 .000 \%$ by the end of the year and poverty levels reached $87 \%$ in 2017 (Reuters 20I8; El Nacional 20I8; El Comercio 20I8; CNN 2018). As stated by the President of the Colombian National Exporters Association, the Venezuelan crisis is so deep that in the last years the country basically disappeared in Colombia's trade balance (Caracol 20I8b). Additionally, the country is also experiencing a political and security crisis. Five Venezuelan cities figure amongst the top 20 most violent cities in the world, with Caracas being the second most dangerous city in that ranking (Wiss 20I8). A situation that could worsen as the social and economic strife goes on.

All of this has generated a growing wave of Venezuelans refugees that

6 Although 8.000 FARC members joined the peace process, by the end of 2017 at least $55 \%$ of them had abandoned it, leaving the concentration zone (El País 20I7). 
are looking for new opportunities across the region. Colombia has been one of the most important destinations, nowadays there are around I.5 million Venezuelans living in the country (Migración Colombia 2019). This situation implies many different challenges for a country that is not used to receive migration and is going through a very unstable political situation after the peace agreement. In this regard, it is important to take into account that many Venezuelans get to Colombia without any resources to survive and others have found there an opportunity to swell the ranks of criminality. On the other hand, the Venezuelan crisis not only means that Colombia must respond to the social challenges that a huge immigration poses, but also to the fact that the border is out of control. The corruption of the Venezuelan institutions makes it extremely difficult to generate cooperation between both countries to fight against the rising criminality in the long frontier. Therefore, this space has turned into a preferred place for criminal gangs and the FARC dissidence to hide and operate.

Furthermore, the diplomatic relations between both governments has been characterized by tensions, with a pragmatic détente promoted by Juan Manuel Santos until 20I7, while his administration negotiated the peace process with the FARC under the Venezuelan facilitation, due to the close ties between this guerrilla with the Bolivarian Revolution'. Nowadays, the tone has risen to such a point, that some Colombian scholars ${ }^{8}$ point out that Venezuela is the first conflict hypothesis for the country. This is justified by the different military incursions that Venezuela has made in Colombian territory and the declaration made by high officials of the Venezuelan governments, saying that they would bomb and destroy important parts of the Colombian infrastructure if the US invades the country (Caracol 20I8a), besides the mobilization of the army in the border (Antolinez 2018). Therefore, the critical situation of Venezuela poses major security challenges to Colombia, as well as its migration crisis put at risk the democratic governability of the region (Mijares \& Rojas Silva 20I8). The country must control illegal immigration and the criminality that can increase with big waves of migration, which is an important task for the National Police. However, when it comes to protect the national borders, fight the Organized Armed Groups operating there, and defend the National Sovereignty, it's the army who plays the main role, so

7 The "Operación Fénix" over Ecuadorian territory was possible due to a phone call of Hugo Chávez to Luis Édgar Devia Silva (A.K.A. Raúl Reyes). The call revealed the geolocation of Reyes' camp (La República 2008).

8 This was a statement made by Professor Diego Vera during the seminar "The new role of the Armed Forces in Bolivia, Brazil, Chile, Colombia, Ecuador and Perú" held in Perú by the Pontificia Universidad Católica del Perú in cooperation with Konrad Adenauer Stiftung. 
they must comply with it.

Related to the above, are the renewed tensions with neighboring Venezuela. That country has been suffering from a process of growing authoritarianism, economic crisis, and increased criminal and political violence (Crisis Group 20I8). Relations with the Santos government had achieved some stability after the rapprochement with Hugo Chávez in August 2010 (Semana 20I0). In addition, the socialist government of Venezuela served as guarantor in the peace negotiations with the FARC, so relations, especially between Santos and Chávez's successor, Nicolás Maduro, maintained a cordial tone. Even in 20I5, when Maduro expelled approximately 20,000 Colombians by force (DW 20I5), Santos' response was not harsh, as he wished to protect the peace process that was being discussed in Havana.

Protests in Venezuela began to be increasingly frequent in 20I4, with the oil prices spike. By 20I7, the repression of the Venezuelan state and its economic collapse had turned Colombia into the main recipient of forced migration from Venezuela (Financial Times 20I8). With the agreement signed, Santos and his government took a turn against Maduro, renewing the tensions that both States have traditionally had, especially since the arrival of the so-called Bolivarian Revolution in 1999. So far, in 2018, the tension has not stopped to rise, and the government of the United States has been discussing with the Colombian one the possibility of contributing to a strategy of regime change in Venezuela (Londoño and Casey 20I8), thus increasing the tension in the border. Since at least 2006 the Venezuelan armed forces have established close relations with Russia, acquiring from them most of their weapons systems (Mijares 20I7). This process of military modernization was derived from the arms embargo applied to Venezuela by the United States since 2000. The most formidable Venezuelan offensive weapons are Sukhoi SU-30 fighter aircraft. These, together with the I92 T-72 tanks, the $29 \mathrm{Mi}$ helicopters, the I3 S-300 antiaircraft systems, and the 2,500 Igla (portable soil-to- air missile launchers), constitute a challenge for a Colombian Military Forces with low air firepower and without tanks (SIPRI 20I8). This has caused an increase in the Colombian military budget in 2019 of I.I billion pesos for the acquisition of an antiaircraft defense system (El Espectador 2018). 


\section{Figure 2: Recent Militarized Incidents Between Colombia and Venezuela (2013-2019)}

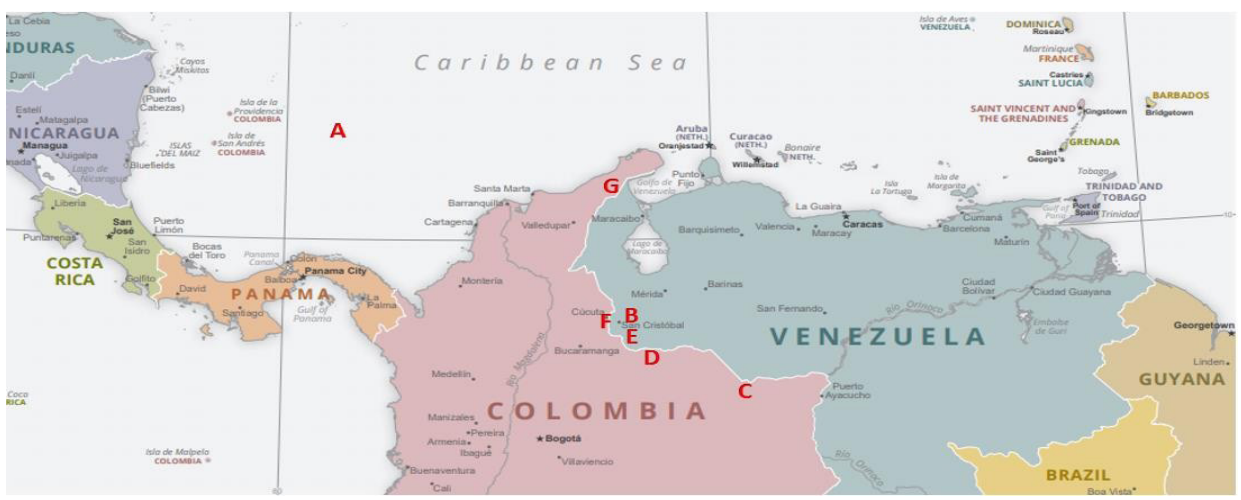

(A) November 2013: Two Russian bombardiers TU-160 violated claimed Colombian air space over the Caribbean in their fly to Nicaragua after joint air combat exercises with the Venezuelan Air Forces.

(B) August 2015: Venezuela claimed that three of its military were wounded by Colombian paramilitary forces in Venezuela's state of Táchira.

(C) September 2015: Colombia claimed that two Venezuelan aircraft fighters SU-30 violated Colombia's air space over the department of Vichada.

(D) March 2017: Colombia denounced the presence of a Venezuelan temporary military base (with almost 50 troops) in the department of Arauca.

(E) July 2017: Colombia denounced the Venezuelan National Guards killed a Colombian civilian in the state of Táchira.

(F) February 2019: Venezuelan militia blocked the humanitarian aid authorized by the opposition National Assembly in the border between the Norte de Santander Department and the Táchira state. (G) June 2019: Shooting among Venezuelan National Guards and unknown gang in the Colombia's department of Guajira.

\section{Source: Prepared by the authors.}

\section{NATO's Global Partnership}

In June 20I8, Colombia officially became the first NATO Global Partner in Latin America (Reuters 20I8). This change implies an increase in Colombian practical cooperation in NATO's global operations, in addition to the establishment of regular and formal dialogue and agreement channels (NATO 20I8). Additionally, the deepening of the relationship with this military alliance, in a convergence of geographical and historical contexts -especially because of the aforementioned situation with Venezuela- implies the need for a doctrinal change for Colombia's defense policy and strategy. Although NATO's Global Partners respond to regional security logics, the demands of this status suppose a process of adaptation to a framework doctrine within 
the 20I0 NATO strategic concept, which establishes a scope of global action (NATO 20IO), creating new conditions for its allies and, by extension for its global partners.

The articulation of the three drivers that are part of the causal mechanism of our explanation, allows inferring causation towards the process of Colombian military transformation. A common feature in them is the change in the environment of conflict that Colombia must face from the second decade of the 2ist century onwards, referring to the change in the conflict hypotheses, in the nature of threats and in military action at three levels: domestic, regional, and global. These changes demand a military transformation that is embodied in the Damascus doctrine, a document that is configured as the most important piece of observable evidence to establish that, in effect, a military transformation is taking place in Colombia.

Thus, these conditions or variables, were the driving forces that contributed to overcome the strong resistance that some military sectors had. We argue that the uneasiness of some military decreased because the three factors already mentioned presented a material reality that was impossible to ignore given that it had an impact on the daily lives of the military forces. Probably, if those factors had not existed, the resistance could have increased or, at least, remained the same. In other words, the unease that could have made much harder the implementation of the military reform, was overcome due to the convergence of national, regional and global conditions that ended up being stronger.

Finally, it is important to mention that there might be other intervenient variables relevant to overcome the military unease and produce the outcome, such as the institutional leadership, namely, the role of the president or of the High Command. However, in our case, a candidate of the opposition assumed the presidency and assigned new personnel in the high military positions. Nevertheless, despite the institutional changes, the transformation process keeps going and the resistance to it has not retrieved strength, at the same time that the three drivers are still present. This allows us to infer that although other variables may have played an important role, the causal path can only be established with the three driving forces that we have proposed.

\section{Final Remarks}

The Colombian military forces are still going through a continuous process of transformation that is mainly evident in the particular case of the army, although facts as the renewed confrontation with Venezuela and the 
NATO partnership give hints to believe that the other forces will also be part of the transformation process. Despite of the resistance in some sectors of the army, the national, regional and international contexts of Colombia are changing, leading to new realities to which the military forces must adapt.

Thus, the changes in the internal armed conflict, Venezuela as a multidimensional threat and the renewed confrontation with this country, and the NATO partnership were identified as the necessary factors that helped to overcome the resistance and produced the military transformation, particularly evident in the new Damascus doctrine. Each one, by themselves are insufficient to explain the transformation but all they were necessary to have this outcome. The unease regarding the military reform has been weakened by the continuous presence and strength of particular conditions in the national, regional and global contexts, leading to the overcoming of that obstacle and the implementation of the transformation. Therefore, despite the resistance, the change of government and the difficulties in implementing the peace process, while in the future the three factors identified remain in the Colombian reality, it is most likely that the military transformation will continue.

Finally, given that there are not recent publications that provide comprehensive explanations for the causality of the Colombian military transformation, this paper aims to present a first approach to understand and explain this case, while making use of a model and methodology that could be applied to other cases. At the same time, it draws attention to the need to keep studying the phenomena related to the military and their roles in the society, given their relevance not only in Colombia, but also in the Latin America as a whole.

\section{REFERENCES}

Antolinez, V. 20I8. "Venezuela moiviliza unidades militares a la frontera con Colombia”. La FM, September 25, 2018. https://www.lafm.com.co/ internacional/venezuela-moviliza-unidades-militares-la-frontera-concolombia

BBC News. 20I6. "Las impresionantes cifras que muestran la dimensión de la guerra en Colombia”. BBC, September 30, 20I6. https://www.bbc. com/mundo/media-37519896

Beach, D., \& Pedersen, R. 20I6. Causal Case Study Methods: Foundations and Guidelines for Comparing, Matching, and Tracing. Michigan: University of Michigan Press.

Caracol. 20I8a. "Chavismo plantea bombardear Colombia en caso de 
intervención de EE. UU”. Caracolradio, August 09, 20I8. http://caracol. com.co/radio/2018/07/09/internacional/I53II4I587-976903.html

Caracol. 20ı8b. "Venezuela desapareció comercialmente para Colombia: Analdex". Caracol Radio, January 28, 20I8. http://caracol.com.co/ radio/20I8/or/26/economia/1516971339-973057.html

CEDOC. 20I6. "Comando de Educación y Doctrina". CEDOC, April I4, 20I6. Available at: https://www.cedoc.mil.co/comando_educacion_ doctrina/conozcanos/plan_minerva_394I66

Ciro Gómez, A. R., \& Correa Henao, M. 20I4. “Transformación estructural del Ejército colombiano. Construcción de escenarios futuros". Revista Científica General José María Córdova, I2 (13).

CNN. 20I8. "La mitad de la economía de Venezuela desapareció". CNN en espaniol, January 25, 2018. https://cnnespanol.cnn.com/2018/oI/25/ la-mitad-de-la-economia-de-venezuela- desaparecio/

Comercio, L. 20I8. "El PIB de Venezuela se hunde un $45 \%$ en tres años y la inflación podría superar el I3.000\%". Libre Comercio, January 29, 20I8. https://www.libremercado.com/20I8-oI-29/el-pib-devenezuela-se-hunde-un-45-en-tres-anos-y-la-inflacion-podria-superarel-13000-I2766I287I/

Cosoy, N. 20I7. "6.900 guerrilleros de las FARC ya están concentrados en 26 zonas en Colombia... ¿y qué sigue ahora?”. BBC News, February 22, 20I7. https://www.bbc.com/mundo/noticias-americalatina-38888897

COTEF. 20I6. "Comando de Transformación Ejército del Futuro". COTEF, October 20I6. Available at: https://www.cotef.mil.co/comando_ transformacion_ejercito_futuro_cotef/conozcanos/resena_historica

Deutsche Welle. 20I5. "Venezuela: expulsan a colombianos de sus casas y las marcan para derribarlas". Deutsche Welle, August 25, 20I5. https:// www.dw.com/es/venezuela-expulsan- a-colombianos-de-sus-casas-ylas-marcan-para-derribarlas/a-I8672133

Duque, Iván. 2018. Bases del Plan Nacional de Desarrollo 2018-2022. Bogota: Gobierno de Colombia. Available at: https://colaboracion.dnp.gov.co/ CDT/Prensa/Plan-Nacional-Desarrollo-2018- 2022-Bases.pdf

El Colombiano. 20I4. "Las Fuerzas Armadas no pueden participar en política: procuraduría”. El Colombiano, June o6, 20I4. http://www. elcolombiano.com/historico/las_fuerzas_armadas_no_pueden_ participar_en_polit ica_procuraduria-AXEC_2976ı

El Espectador. 2orı. "Éxito de Operación Odiseo, muerte de 'Alfonso Cano”. 
El Espectador, November I6, 20II. https://www.elespectador.com/ noticias/judicial/exito-de- operacion-odiseo-muerte-de-alfonso-canoarticulo-30973I

El Espectador. 20I7. "Bajó un 97 \% la cifra de soldados heridos: Hospital Militar”. El Espectador, July I2, 20I7. https://www.elespectador.com/ noticias/nacional/bajo-el-97-la-cifra-de-soldados-heridos-hospitalmilitar-articulo-702742

El Nacional. 2or8. "OVCS: La pobreza en Venezuela pasó de 48,4\% en 2014 a $87 \%$ en 20I7". El Nacional, September 02, 20I8. www. el-nacional.com/noticias/economia/ovcs-pobreza-venezuelapaso-484-20I4-20I7_250228

El Pais. 20I7. "El 55\% de los guerrilleros de las FARC han abandonado las zonas veredales, dice la ONU”. El País, November 2I, 20I7. https:// www.elpais.com.co/proceso-de- paz/el-55-de-los-exguerrilleros-de-lasfarc-han-abandonado-las-zonas-veredales-dice-la- onu.html

El Tiempo. 20i6. "Ejército de Colombia renueva su doctrina después de ı०o años". El Tiempo, August o6, 20I6. https://www.eltiempo.com/ justicia/cortes/ejercito-presenta-su- doctrina-damasco-2948

El Tiempo. 20I7. "Muertes por conflicto bajaron de casi 3.000 en el 2002 a cero este año". El Tiempo, November i8, 20I7. https://www.eltiempo. com/justicia/conflicto-y-narcotrafico/el- cerac-dice-que-las-muertespor-el-conflicto-bajaron-en-el-20I7-I52744

El Tiempo. 20I7. "Venezolanos, la migración más grande en la historia de Colombia". El Tiempo, March 30, 20I7. https://www.eltiempo.com/ especiales/migracion-de-venezolanos- en-colombia-cifras-e-historiasde-vida-72946

Ellis, E. 20I6. "Strategic Insights: The Post-Conflict and the Transformation of Colombia's Armed Forces”. Strategic Studies Institute. Available at: http://ssi.armywarcollege.edu/index.cfm/articles/ColombiasArmed-Forces/2016/08/17

Finantial Times. 2018. "Colombia grapples with wave of Venezuela migrants". Finantial Times, 20I8. https://www.ft.com/content/4eaI28fc-ba87IIe8-94b2-I7I76fbf93f5

García, H. 20I8. "El cara a cara en el poder militar entre Colombia y Venezuela". El Espectador, September 22, 20I8. https://www.elespectador.com/ noticias/politica/el-cara-cara-en-el-poder-militar-entre-colombia-yvenezuela-articulo-813742

Group, I. C. 2018. "How to Respond to Venezuela's Humanitarian Emergency”. International Crisis Group, September 25, 2018. https:// 
www.crisisgroup.org/latin-america-caribbean/andes/venezuela/howrespond-venezuelas-humanitarian-emergency

IndexMundi. 20I7. Colombia profile. Available at: https://www.indexmundi. com/colombia/

Jeffrey, Alex. 2006. "Building state capacity in post-conflict Bosnia and Herzegovina: The case of Brcko District". Political geography 25.2 (2006): 203-227.

Jingushi, A. W. 2015. "Post-Conflict Security Sector Reform, and the Roles of the Military and the Police: The Case of Sierra Leone". NIDS Journal of Defense and Security, 37-59.

León, J. 20I4. "Los cuatro temores de los militares frente al proceso de paz". La Silla Vacia, Octubre 29, 20I4. https://lasillavacia.com/historia/ historia-militares-juanita-49005

Londoño, E., \& Casey, N. 2or8. “Trump Administration Discussed Coup Plans With Rebel Venezuelan Officers". The New York Times, September 08, 20I8. https://www.nytimes.com/2018/09/08/world/ americas/donald-trump-venezuela-military- coup.html

Lozano, P. 20I0. "Muere en un bombardeo el jefe más sanguinario de las FARC". El Pais, September 23, 20I0. https://elpais.com/ internacional/2010/09/23/actualidad/I285192803_8502I5.html

Merchán, R. 2005. “¿Un Estado colapsado?”. Semana, July ı, 2005. http:// www.semana.com/opinion/articulo/un-estado-colapsado/73598-3

Mijares, V. M. 20I7. “Soft Balancing the Titans: Venezuelan Foreign-Policy Strategy Toward the United States, China, and Russia”. Latin American Policy, 20I-23I.

Mijares, Víctor M., \& Nastassja Rojas Silva. 20ı8. "Venezuelan Migration Crisis puts the Region's Democratic Governability at Risk". Latin American Policy (20I8): I3.

NATO. 20I0. "Strategic Concepts”. NATO, June I2, 20I0. https://www.nato. int/cps/en/natohq/topics_56626.htm

NATO. 20I8. "Relations with Colombia". NATO, May 3I, 20I8. https://www. nato.int/cps/ra/natohq/topics_I43936.htm

OACP. 20I7. "ONU finaliza el proceso de dejación de armas y entrega las cifras consolidadas del armamento recibido e inhabilitado de las Farc". Oficina del Alto Comisionado para la Paz, September 22, 2017. http://www.altocomisionadoparalapaz.gov.co/Prensa/Paginas/20I7/ Septiembre/onu-finaliza-dejacion-armas-entrega-cifras-consolidadasarmamento-recibido-inhabilitado.aspx 
Portafolio. 20I7(09. abril 20I7). 8.376.463: las víctimas del conflicto armado en Colombia. Portafolio, April o9, 20I7. http://www.portafolio.co/ economia/gobierno/el-numero-de-victimas-del-conflicto- armado-encolombia-504833

Prezelj, I., Kopac, E., Vuga, J., Ziberna, A., Kolak, A., \& Grizold, A. 2015. "Military Transformation as Perceived by Experts". The Journal of Slavic Military Studies, 23-47.

RCN. 2018. "Hospital Militar pasó de atender izo a un solo soldado herido por la guerra”. RCN Radio, May 28, 2018. https://www.rcnradio. com/colombia/hospital-militar-paso-de-atender-I3o-un-solo-soldadoherido-por-la-guerra

Reuters. 20I8. "Colombia to be NATO's first Latin American global partner". Reuters, May 26, 2018. https://www.reuters.com/article/us-colombianato/colombia-to-be-natos-first-latin-american-global-partneridUSKCNIIRoE8

Rico, M. 2008. “Así fue la Operación Fénix”. El Pais, March o9, 2008. https:// elpais.com/diario/2008/03/09/internacional/I2050I7202_8502I5. html

Rojas, P. J. 20I6. “Doctrina Damasco: eje articulador de la segunda gran reforma del Ejército Nacional de Colombia”. Revista Científica General José María Córdova, (Jan-Jul) pp. 95-II9.

Rojas, P. J. 20I7. "Damascus: The Renewed Doctrine of the National Army of Colombia". Journal of Military and Strategic Studies, S. 263-272.

Semana. 20I0. "Colombia y Venezuela restablecen las relaciones diplomáticas". Semana, October o8, 20I0. https://www.semana. com/nacion/articulo/colombia-venezuela-restablecen-relacionesdiplomaticas/120388-3

Semana. 20I3. “¿Quién le filtró a Uribe las coordenadas?”. Semana, August 04, 20I3. https://www.semana.com/nacion/articulo/quien-le-filtrouribe-las-coordenadas/339294-3

Semana. 20I4. “¿Alguien espió a los negociadores de La Habana?”. Semana, March 02, 20I4. https://www.semana.com/nacion/articulo/alguienespio-los-negociadores-de-la-habana/376076-3

Semana. 20I6. "Cifras del conflicto armado en Colombia". Semana, June 25, 2016. https://www.semana.com/nacion/articulo/cifras-del-conflictoarmado-en-colombia/479210

Shifter, M., \& Jawahar, V. 2004. “State building in Colombia: Getting priorities straight”. Journal of International Affairs, I43-I54. 
SIPRI. 20I6. "Military Expenditure as a share of GDP". SIPRI. Available at: https://www.sipri.org/sites/default/files/3_Data\%2ofor\%2oall\%20 countries\%2ofrom\%201988\%E2\%80\%932017\%20as\%20a\%20 share\%20of\%20GDP.pdf

SIPRI. 20I8. SIPRI Arms Transfers Database. Available at: https://www. sipri.org/databases/armstransfers

Toro, Y. 20IO. "La seguridad, el legado histórico de la era Uribe”. El Pais, July I9, 20I0. https://www.elpais.com.co/judicial/la-seguridad-el-legadohistorico-de- la-era-uribe.html

Wiss, J. 20I8. “Caracas es la capital más peligrosa del mundo”. El Nuevo Herald, March o8 2018. https://www.elnuevoherald.com/noticias/ mundo/america-latina/venezuela- es/article204233459.html

WOLA. 20I5. "Colombia's Military and the Peace Process". WOLA Colombia Peace, January 24, 20I5. http://colombiapeace.org/20I5/OI/24/ colombias-military-and-the-peace- process/

World Bank. 2or6. "Armed Forces Personnel Total". The World Bank Data. Available at: https://data.worldbank.org/indicator/MS.MIL.TOTL. PI?locations $=\mathrm{CO}$

World Bank. 20I8. “Colombia GDP”. World Bank Data. Available at: https:// data.worldbank.org/country/colombia

\section{ABSTRACT}

After the signing of the peace in Colombia, attention has been directed to the difficult process of implementing the agreements. This complex scenario has downplayed the problem of Colombian military transformation. The basis of that transformation, the Damasco doctrine, has encountered resistance within the Colombian Military Forces. Through the application of the method of process tracing, we infer that there is a non-linear, and in progress, process towards the fulfillment of the objectives of the doctrine. Thus, we identify three drivers that are making this transformation advance: a renewed confrontation with Venezuela; the changing nature of the domestic conflict; and the status of Colombia as a NATO global partner.

\section{KEYWORDS}

Military Transformation; Damasco Doctrine; Colombian Military Forces; Colombian Peace Agreements; Process Tracing. 